\title{
92 cines. Los cines de Santiago Rodrigo Avilés
}

\author{
Vicente Vargas Estudio - Taller del Error Perpetuo, \\ Santiago, Chile, 2012, 154 págs.
}

\section{Tomás Cornejo}

Universidad Diego Portales, Santiago, Chile. Email: tomas.cornejo@udp.cl

Con este volumen el fotógrafo Rodrigo Avilés intentó documentar las transformaciones de los recintos de exhibición cinematográfica de la capital chilena a partir del año 2000. Es un registro fotográfico que, con imágenes realizadas por el autor tanto en blanco y negro como en color, da cuenta de las reutilizaciones o desapariciones de las salas capitalinas, proponiendo con ello una lectura de la ciudad, el espacio público y el cine como industria cultural.

92 cines es un ensayo fotográfico que se acerca al límite de no incluir texto alguno, con la excepción de dos breves planas escritas por el propio Avilés y por el artista visual Jordi Colomer (traducidos ambos al inglés).

El recorrido que propone el libro es, sin embargo, equívoco. El orden de las fotografías es alfabético y viene determinado por el nombre de cada sala. Podría pensarse en organizaciones alternativas del material, que permitieran comprender mejor cómo los habitantes de Santiago experimentaron el fenómeno del cine y la eventual conformación de cartografías urbanas derivadas de dicha experiencia. Una edición distinta ilustraría mejor la polaridad entre las grandes salas de la primera mitad de siglo y los cines de barrio, exponentes que de una y otra categoría aparecen como raros sobrevivientes si bien muy metamorfoseados- en el libro en cuestión. De pretensiones lujosas y ligadas a las grandes distribuidoras de la mercancía cinematográfica, las primeras fueron pensadas, como señala Colomer, como palacios para el cine, templos para contemplar imágenes en movimiento. Sus nombres evocaban esa fastuosidad (por ejemplo, el cine Alhambra), o eran invitaciones a una experiencia vicaria de las luces de las metrópolis mundiales (el Lido, el Metro, el Gran Palace).

Los cines de barrio, en cambio, que según el historiador Jorge Iturriaga florecieron desde 1910 en el radio exterior al centro histórico de la ciudad, fueron claros indicadores del crecimiento demográfico santiaguino y la extensión de sus suburbios, habitados por hombres y mujeres de las clases trabajadoras que encontraron en estas salas de vocación masiva y popular un medio de entretención e información muy barato y accesible, con funciones rotativas y programas dobles o triples. Según un catastro de 
la Intendencia de Santiago en 1913, sobresalían asimismo nombres de otro cariz para estas salas: Arturo Prat, Independencia, Biógrafo San Eugenio, Biógrafo Italia. En tal sentido, y de acuerdo a lo que se aprecia en el propio libro, no deja de llamar la atención la disparidad en el emplazamiento y el tamaño de algunos de estos últimos cines, al compararlos con salas como El Golf, Las Condes o el ñuñoíno California, que acompañaron el desplazamiento de las clases medias y altas hacia el oriente de la capital.

Otro tanto surge, en términos de la relación entre cines y espacio urbano, respecto de la actual concentración del llamado cine para adultos en pleno centro de Santiago. ¿Cuándo sucedió que el Capri, el Roxy, el Montecarlo o el Huelén dejaron de pasar estrenos hollywoodenses o reponer éxitos de taquilla para concentrarse en cintas eróticas o porno? Sus luces de neón y sus avisos llamativos salpican de colores el deambular por las galerías de cualquier transeúnte que recorre el corazón mismo de la ciudad.

Esta inquietud proviene de la intención manifiesta de92 cines de ponderar críticamente el estado actual de la exhibición cinematográfica, cuyas marcas urbanas más visibles son las salas demolidas o convertidas en algo muy distinto al propósito para el cual fueron construidas. El autor enseña éste como un proceso de decadencia urbana, palpable en una dimensión arquitectónica (cf. el Cine Santa Lucía, en plena Alameda, en trance de ser demolido), pero sobre todo política. El reciclaje de los cines en Santiago se ha producido, de acuerdo al registro visual que entrega Avilés, en dos direcciones principales. La primera, un reciclaje económico, donde el espacio cinematográfico lo ha ocupado el comercio bajo modalidades muy disímiles, que incluyen centros de diversión nocturna, grandes tiendas departamentales y empresas de giros muy variados (de las cuales los gimnasios, y la adaptación de una sala de cine en cancha de squash, que ha sido plasmada en la portada, son el paroxismo). En tales casos, el emplazamiento céntrico y la calidad de muchas de las construcciones han vuelto atractivos los inmuebles otrora pensados como lugar de encuentro de los capitalinos con las producciones de la fábrica de sueños.

El segundo tipo de reciclaje es más bien ideológico y parece no circunscribirse al centro de Santiago, sino que ha ido distribuyéndose por toda la traza urbana: la utilización de los cines como sede de iglesias o agrupaciones religiosas de variados credos y denominaciones. Tanto una como otra forma de reciclaje son degradaciones del espacio público citadino, entendido como instancia de debate social del cual el cine, a lo largo del siglo XX, fue parte fundamental. Aunque, a diferencia de lo expresado por Avilés, tal degradación no debe ser circunscrita al orden autoritario y neoliberal de las últimas décadas. Concuerdo con que los embates de éste han afectado nuestra experiencia del hecho fílmico, recluyéndonos como espectadores en esos antros luminosos y abarrotados de mercancía no cinematográfica llamados multi-salas, donde las cintas hoy digitales- han perdido preponderancia frente a golosinas y refrescos. Pero tampoco se debe idealizar al cine de décadas pasadas; desde su nacimiento o, para ser más 
precisos, desde que se concibió al cinematógrafo como producto comercial masivo y, en nuestro continente, las películas estadounidenses terminaron por imponerse a las europeas en los años posteriores a la Primera Guerra Mundial, el cine fue una industria cultural consolidada. Y una de las más penetrantes en términos ideológicos, cabría agregar, ya que proveyó de modelos representacionales (de clase, de género, sexuales, raciales y nacionales, entre otros) a varias generaciones. Este fue uno de los desafíos que acometió, desde la década de 1960, el heterogéneo grupo de realizadores que se agrupó en los nuevos cines latinoamericanos, abocándose a una labor encomiable, si bien no tan fructífera, de descolonización. Uno de los escollos insalvables de esa tarea fue, en efecto, la distribución, cuya fase definitiva de encuentro con los espectadores no se verificó de manera feliz en las salas que Avilés ha fotografiado. En ellas, la apropiación cultural del cine como objeto artístico, medio de comunicación y mercancía para el consumo masivo, se dio según unos patrones siempre desfavorables para la creación local y que deben pensarse en relación con redes de intercambio de imágenes e imaginarios de alcance global. 